\title{
6 \\ Policy Impediments to Social Investments by Australian Businesses
}

\author{
Leeora D. Black
}

\section{The role of business in social investment}

The term 'social investment' has been used loosely by Australian business to denote any philanthropic contribution to society, sometimes as part of corporate social responsibility (CSR) programs or corporate foundation grant making. Corporate social investment (CSI) can entail donations, managerial expertise or use of corporate infrastructure and resources (Cooke 2010).

Definitions of CSI are often very broad. For example, KPMG's report on Unlocking the Value of Social Investment (2014: 4) says social investment is '[a]ny investment a company makes to contribute to society that is not primarily motivated by generating a direct financial

1 I am grateful for the support and advice of a number of people in preparing this chapter: Jacqueline Hartford, intern, ACCSR (RMIT University); Corinne Proske, Director, Government, Education and Community, Head of Community Finance and Development, National Australia Bank; Daniel Madhavan, Chief Executive Officer, Impact Investing Australia; and Ainsley Lee, Head of Investments, NRMA Strategy \& Investments. 
return'. This includes donations, sponsorship, volunteering, matched giving and pro bono work, all of which are the traditional tools of corporate philanthropy.

This definition represents a traditional view of CSI. Newer definitions directly challenge the view that CSI is incompatible with financial returns. Social investment can unlock significant sums of private investment capital, according to the Global Impact Investing Network (www.thegiin.org) and local organisations such as Impact Investing Australia (impactinvestingaustralia.com/). Big Society Capital (bigsocietycapital.com/), a UK-based financial institution with a social mission set up to help grow the social investment market, defines social investment as 'the use of repayable finance to achieve a social as well as a financial return'. Compared with traditional views of CSI, the goal of social impact investment is very specific: to catalyse viable private markets to address pressing social needs.

Impact Australia estimates the market for social impact investment could reach $\$ 32$ billion in a decade (NSW DPC 2015), whereas, in 2013, philanthropic donations from businesses in Australia amounted to more than $\$ 850$ million (Philanthropy Australia n.d.). Social impact investment suggests a much more promising avenue for achieving significant social outcomes. Therefore, I have chosen in this chapter to use the Big Society Capital definition of social impact investment as the lens through which to examine social investments by Australian business, or CSI.

Social investments by Australian businesses that adopt an impact investment orientation are, so far, in their infancy. In this chapter, I will suggest three new opportunities for social investments by business and describe some potential roles for government in stimulating this innovative approach to achieving social outcomes. The concept of 'shared value' (Porter and Kramer 2011) holds promise for increasing social investments by business. I will then describe policy impediments to further social investment by business and suggest some potential solutions. 


\section{Three opportunities for social investments by business}

There is significant potential to expand social investment by business through financial intermediaries, superannuation funds and CSR programs.

\section{Banks and other financial intermediaries}

Banks and other financial intermediaries such as credit unions or investment banks can use their financial strength to develop innovative approaches to funding social enterprises. A social enterprise is a business that aims to make a social impact as well as generate a financial return. There may be more than 20,000 social enterprises in Australia (Social Traders and QUT 2010).

One example is STREAT, a social enterprise that aims to address youth homelessness and disadvantage, bringing about social change through market-focused business activities, such as food services businesses. STREAT sought a bank loan of $\$ 1.5$ million to develop a property to set up a food business. The property was leased from a private investor for a peppercorn rent of $\$ 1$ a year. That kind of arrangement does not provide the collateral that a traditional bank loan requires. Most banks would have looked at it simply on a traditional commercial basis and said no.

STREAT's bank, however, the National Australia Bank (NAB), was very keen to support the organisation's vision due to their own CSR orientation, and worked to get the deal up for them.

More recently, NAB has signed a further \$2.5 million loan for STREAT to help finance the construction of a new multimillion-dollar training facility for Melbourne's homeless youth (Christie 2015). The facility will train 250 young homeless Australians each year and give them the opportunity of a career in hospitality. Importantly, the deal will help STREAT transition to a fully self-funded business model. STREAT is not required to make any interest payments during construction, with the value of the property providing security during the building phase. After the facility has been built, the debt will be sold to investors. 
Other successful impact investments in Australia are the Good Start Early Learning Centre, Australian Chamber Orchestra Instrument Fund, Barefoot Power and Hepburn Community Wind (Addis et al. 2013).

Intermediaries play an important role in bringing the supply of money and the demand for capital together in the social impact investment market (Burkett 2012; Addis et al. 2013). Financial intermediaries can take a wide range of forms and roles, from advisers to institutions that can assist with raising capital.

Impact Australia points out that intermediaries are particularly critical when the sector is still developing, as there are fewer established pathways to connect supply and demand, and there is a need for systemic ways for supply and demand to 'find' each other (Addis et al. 2013).

Skilled professionals who can match investors with social enterprises are required. A need for intermediation is a strong and consistent theme in the Australian market (Senate Economics References Committee 2011). There is potential for specialists to enter the sector and structure impact investment deals and products, and it is expected that demand for such intermediaries will increase (Addis et al. 2014).

\section{Superannuation funds}

It was not until the 2006 federal government report on The Social Responsibility of Corporations (CAMAC 2006) that it was made clear that it is in the interests of long-term investors such as superannuation funds to take social factors into account in their investment decisions. That same year the Parliamentary Joint Committee on Corporations and Financial Services report on corporate responsibility (PJC 2006) strongly encouraged superannuation trustees to consider companies' environmental and social responsibilities. The report stated, 'it is in fact so far bound up in long term financial success that a superannuation trustee would be closer to breaching the sole purpose test by ignoring corporate responsibility' (PJC 2006: s. 5.41). A decade on and about 50 per cent of Australian total assets under management now consider environmental, social and governance factors (RIAA 2015).

Involvement of the superannuation sector in social investment, however, remains all but non-existent. One exception is the industry superannuation fund HESTA. In September 2015, it announced 
a $\$ 30$ million social impact investment fund brokered through Social Ventures Australia (Appell 2015). The fund will use a combination of debt, equity and social impact bonds to target deal sizes between $\$ 1$ million and \$10 million (Oppes 2015).

\section{CSR programs}

CSR programs have been moving to a more strategic orientation for many years; however, the use of innovative financial instruments to drive social as well as financial outcomes is not well established in corporate Australia. This is despite the fact that the biggest proportion of CSR budgets generally goes into community investment (ACCSR 2014).

Unlike most large businesses, NRMA Motoring, a New South Walesbased membership association, seeks social as well as financial outcomes from its investment portfolio. NRMA Motoring held three social investments, according to its 2015 sustainability report (NRMA 2015), including social benefit bonds (SBBs) and a direct investment in a social venture.

NRMA Motoring's approach is unusual, but may become more popular as business increasingly understands the role it can potentially play in driving better social outcomes by addressing social problems through business innovation.

Banks could play a positive role in stimulating social investment through CSR programs by creating new financial vehicles along the lines of climate impact bonds to enable other companies to invest a portion of their community spend in impact investments.

\section{Shared value}

The concept of shared value (Porter and Kramer 2011) holds promise for increasing social investments by Australian businesses. Shared value is a business strategy that delivers an improved profit formula or new market opportunity by addressing societal challenges. Its authors claim to be reshaping the traditional corporate response to societal issues. It calls for business to address social issues relevant to their business by innovating at scale through three potential pathways: redefining products and markets, redefining productivity and creating enabling local environments. 
Nestlé's work with SA farmers to secure its supplies of oats for the Uncle Toby's brand is a good example of shared value. Nestlé worked with farmers and the South Australian Research and Development Institute to develop oat breeds that deliver better quality and yields, are disease and drought tolerant and contain higher beta-glucan content. This program not only gives Nestlé certainty of supply and a better-quality milling oat, it also gives farmers a guaranteed return and oats better suited to their conditions. It also gives consumers a more nutritious product.

This form of shared value has much in common with strategic CSR (Burke and Logdson 1996); however, rising interest in shared value in Australia may lead to more corporate social investments with significant economic and social benefits beyond the firm. Sharedvalue approaches are also compatible with social impact investments.

\section{Obstacles to social investment by business}

The barriers to further social investment by Australian business are numerous and well canvassed in several reports by the Senate Economics References Committee (2011), Impact Investing Australia and others (for example, Addis et al. 2013, 2014). They include: lack of access to early stage risk capital; lack of data; limited investments and high transaction costs; cultural barriers; lack of taxation incentives; the absence of clear policy to assist growth and encourage investment; and the lack of benchmarking and measurement.

The NSW Government identified barriers to the growth of social impact investment in New South Wales in its 2015 Social Impact Investment Policy. Barriers include:

[L]imited proven models to build investor confidence, a lack of quality data to measure and quantify outcomes, diverse views on how to measure outcomes, the need for government to see genuine risk sharing in transactions, sufficient capability and capacity across government and social sector organisations, and economies of scale and diversification necessary for larger investors and funds to invest. (NSW DPC 2015: 3)

In a report written for the United Kingdom's Social Impact Investment Taskforce, Triodos Bank identified regulation as a barrier to impact investing by setting minimum investment levels too high and thereby 
restricting the pool of potential investors (Social Impact Investment Taskforce 2014). A further barrier is that the majority of tax incentives are aimed only at mainstream investments such as mutual funds and stock investments.

In Australia, the deductible gift recipient (DGR) rules of the taxation system mean that charities with DGR status can receive tax-deductible gifts from donors, but they must be established entities. Early stage social entrepreneurs are very unlikely to qualify for tax-deductible gifts or investments (Senate Economics References Committee 2011). Private ancillary funds (PAFs) can fund only DGR-status organisations and have poor incentives to make social investments (Senate Economics References Committee 2011). Further, the social sector is prohibited by DGR and PAF requirements from using grants for investment, and must buy 'stuff' (private communication, 2015).

The Australian Treasury (2014) has concluded that clarification of regulation would help facilitate market development. Such clarification might include financial obligations for superannuation companies and amendments to laws to facilitate private investors to access social impact bonds. Currently, social impact bonds are burdened by onerous disclosure requirements. The report recommends exploring ways to facilitate the development of the impact investment market and encouraging innovation for funding, and provide guidance to superannuation companies on impact investing.

It is frequently harder for social enterprises than for commercial enterprises to access funds. Social entrepreneurs' risk profile is too high for regular finance arrangements and too costly for banks to go the extra mile.

Finally, the mindset for CSR programs is not attuned to the concept of investment for a financial return, rather than grants. The result is a weak deal pipeline and poor capacity of social sector organisations to pursue social investments. 


\section{The role of government in social investment by business}

Government can play a variety of roles in stimulating social action by business: mandating, facilitating, collaborating and endorsing (Fox et al. 2002). Governments in Australia have so far adopted a 'facilitating' approach. In a facilitating role, governments act as a driver for social and environmental change through enabling or providing incentives for organisations. There is also opportunity for governments to encourage participation from investors through raising awareness, as well as developing management tools, benchmarks and guidelines (Fox et al. 2002: 5). Governments can also act as underwriter, co-investor, regulator, procurer of goods and services or provider of subsidies and technical assistance (Wood et al. 2013).

The World Economic Forum (WEF 2013) has three recommendations for the role of government in social impact investing. The first is to 'provide tax relief for risky or early stage investments in which public benefit is created, but below-market returns are generated' (WEF 2013: 29). The purpose of this recommendation is to catalyse investment in projects that might provide below-market returns and may be avoided by investors unless there is an incentive. The second recommendation is to '[c]autiously revise regulations that restrict willing capital into impact investments' (WEF 2013: 29). If regulation is restricting investment, changes to regulation may reduce barriers and encourage increased capital flow. The third recommendation is to 'help de-risk the ecosystem through innovative funding mechanisms. Ways governments can do this are to provide access to capital, and take a subordinate position in a layered structured fund to attract mainstream investors (WEF 2013: 29).

Recently, some Australian state governments have announced programs, or their intention to establish programs, to facilitate social impact investment. This increased involvement by government has raised questions as to what role the public sector can play in breaking down barriers to impact investment in Australia. 
In January 2015, the NSW Government released its Social Impact Investment Policy. The policy outlines the future direction for social impact investment, building on existing SBB programs such as Newpin and the Benevolent Society Bond.

In July 2015, the Queensland Government announced it would undertake a SBB pilot program (Pitt 2015). Three SBBs will be piloted, targeting early intervention in social issues such as reoffending, homelessness and childhood education. A Social Benefit Bonds Readiness Fund will also be set up to assist providers in the design phase of the pilot (Remeikis 2015).

Currently, the SA Government is moving towards trialling social impact bonds and received expressions of interest for social impact investment up to 20 February 2015, after releasing a discussion paper (SAG 2015).

The governments of Victoria, Western Australia and Tasmania are in various stages of developing social impact investment initiatives (Charlton et al. 2013). In response to recommendations arising from the 2015 Review of Australia's Welfare System, the then federal minister for social services, Scott Morrison (Mather 2015), has also outlined his enthusiasm and support for an increased role for social impact bonds in addressing social issues.

\section{Policy options for Australia}

In this section, I describe some policy options for government to consider to stimulate greater social investment by business.

\section{New business structures}

Currently, a company structure can be either for-profit or not-forprofit (NFP). NFP companies are prohibited from making distributions to members or paying fees to directors (ASIC 2011), meaning there can be no investments with financial returns. For-profit company directors are required to act in the best interests of the company, which does not exclude taking social impacts into consideration (PJC 2006); however, a permissive approach is not the same as encouragement. 
In the United States, a new form of corporate structure has been authorised in 30 states and the District of Columbia: the 'B Corporation' (Wikipedia 2016). B corporations differ from traditional companies as they specifically seek a positive impact on society and the environment, in addition to returns for shareholders. While nothing in Australian corporations law prohibits social benefits as well as financial returns, neither is there much encouragement.

The B corporation movement established a presence in Australia in 2014 (B Lab n.d.) and is canvassing perspectives on the establishment of a new legal form in Australia that considers impacts not only on shareholders, but also on society and the environment. In Australia, B corporations are certified based on an assessment of the company's governance, transparency and environmental and social impacts, and not on a separate legal form.

Arguments for creating a legal form for B corporations in Australia include giving specific legal protection to directors and officers to consider the interests of all stakeholders, not just shareholders (that is, creating a safe harbour for directors), and helping mission-driven businesses to attract venture capital and command higher valuations.

But the more powerful and urgent argument is the ability to direct capital into business that can address social impacts at scale.

\section{Encouraging shared value}

Governments can play a significant role in changing mindsets, raising awareness and encouraging action (Fox et al. 2002). The Australian Government has so far used a shared-value approach to encouraging business investment in foreign aid through its 'Ministerial statement on engaging the private sector in aid and development: Creating shared value through partnership' (DFAT 2015), released on 31 August 2015. However, more could be done to stimulate business investment in addressing social problems in Australia through supporting shared-value education and training, partnering with business and establishing intermediary organisations with the capacity to bring investors and investees together. 


\section{Support for intermediary organisations}

The UK Government, for example, established Big Society Capital in April 2012 to grow the social investment market. Big Society Capital's first annual report outlines the UK Government's policy development journey since 2000 that led to its establishment (Big Society Capital 2012). Big Society Capital makes direct investments as well as working with others to facilitate deals and raise awareness. Funding is provided from dormant bank accounts and banks. At 30 June 2015, Big Society Capital reported $£ 370$ million (A $\$ 713$ million) invested in a portfolio of 39 charities and social enterprises.

An Australian body that undertakes a similar role to Big Society Capital would be an important enabler of the emerging social investment market.

\section{Taxation}

Unlike Australia, the UK Government provides some tax relief for investments (not just donations) in charities and social enterprises. In a submission to the federal government's tax White Paper process, Social Ventures Australia (SVA 2015) released a tax discussion paper that called for tax concessions for impact investments in social enterprises, social impact bonds and social and affordable housing projects.

The SVA submission recommended:

1. Investors be able to offset the amount invested in a social enterprise or social impact bond against their assessable taxable income in the year that the investment is made.

2. Investors receive a tax exemption for interest repayments or dividends as they are repaid during the life of the investment.

3. Capital gains tax should also be exempt when the impact investment is held for a minimum period.

4. A new social infrastructure tax offset scheme should be implemented using non-deductible/non-assessable social and affordable housing bonds so that investors can lend at submarket rates to developers building new social and affordable housing stock. 


\section{Sole-purpose test}

The 'sole-purpose test' requires superannuation fund trustees to manage funds solely for the benefit of fund members' retirements (APRA 2011). This does not prohibit positive social outcomes (PJC 2006). Indeed, environmental, social and governance considerations are now mainstream (RIAA 2015). However, this is not the same as putting social impacts on a par with financial returns. It is possible for superannuation funds to seek positive social impacts, as demonstrated by the establishment of Good Super in 2013 (goodsuper. com.au), which has 100 per cent of funds in impact investments, and Christian Super in 1984 (christiansuper.com.au/), with about 10 per cent of funds in impact investments (Impact Investing Australia n.d.). As noted earlier, HESTA has committed to a $\$ 30$ million social impact investment fund.

The sole-purpose test allows superannuation funds to invest for positive social outcomes where returns are comparable with commercial rates of return; however, others have argued that funds can invest in vehicles that provide a lower commercial rate although they generally avoid doing so (Senate Economics References Committee 2011). The committee called for clarification, if necessary, of the fiduciary duties of superannuation funds and their ability to engage with social impact investment opportunities (Senate Economics References Committee 2011: Recommendation 4.4).

A clear statement by government that positive social impacts are consistent with the sole-purpose test may help to embolden investors to participate in new types of social investments.

\section{Conclusion}

In this chapter, I have argued that greater social investment by business can be unlocked by adopting a view of social investment that encourages the pursuit of financial, as well as social, returns. I have suggested that banks, superannuation funds and CSR programs all have a significant role to play in unlocking this potential. Corporations law and our taxation system provide little encouragement for this type of social investment by business, but that could change with thoughtful policy approaches. Governments are beginning to welcome 
experiments with social impact investing but much more is possible. Some of the ways in which governments can encourage greater social investment by business are: the encouragement of shared-value approaches; the use of $\mathrm{B}$ corporation structures to unlock social entrepreneurship; capacity and pipeline-building initiatives along the lines of the United Kingdom's Big Society Capital; the use of taxation incentives; and clarification of the sole-purpose test.

\section{References}

Addis, R., A. Bowden and D. Simpson. 2014. Delivering on impact: The Australian Advisory Board breakthrough strategy to catalyse impact investment. Australian Advisory Board report to Impact Investing Australia, Melbourne.

Addis, R., J. McLeod and A. Raine. 2013. IMPACT-Australia: Investment for social and economic benefit. Canberra: Commonwealth Department of Education, Employment and Workplace Relations and JBWere.

Appell, D. 2015. 'Australia's HESTA commits A $\$ 30$ million to social impact fund.' Pensions \& Investments, 3 September. Available from: pionline.com (accessed 3 December 2015).

Australian Centre for Corporate Social Responsibility (ACCSR). 2014. 'The 10th year: Progress and prospects for CSR in Australia and New Zealand.' In Annual Review of the State of CSR in Australia and New Zealand, 12. Melbourne: ACCSR.

Australian Prudential Regulation Authority (APRA). 2011. The sole purpose test. Superannuation Circular No. III.A.4, February. APRA, Sydney.

Australian Securities Investment Commission (ASIC). 2011. Registering not for profit or charitable organisations. Information Sheet 81, November. ASIC, Sydney. Available from: asic.gov.au/for-business/ starting-a-company/how-to-start-a-company/registering-not-forprofit-or-charitable-organisations/ (accessed 9 December 2015). 
B Lab. n.d. Developing Model Legislation for Australian B Corps. Melbourne: B Lab. Available from: bcorporation.com.au/ benefitcorp_au (accessed 9 December 2015).

Big Society Capital. 2012. Annual Report. London: Big Society Capital.

Burke, L. and J. M. Logsdon. 1996. 'Corporate social responsibility pays off.' Long Range Planning 29(4): 437-596.

Burkett, I. 2012. Building Blocks for Action: Place based impact investment in Australia. Canberra: Commonwealth Department of Education, Employment and Workplace Relations, NAB, Mission Australia and JBWere.

Charlton, K., S. Donaid, J. Ormiston and R. Seymour. 2013. Impact Investments: Perspectives for Australian superannuation funds. Sydney: Herbert Smith Freehills, Evans \& Partners, The Ian Potter Foundation, Macquarie Funds Group, Macquarie Group Foundation and University of Sydney.

Christie, R. 2015. 'NAB expands social impact investment offerings.' InFinance, 9 June. Available from: finsia.com/news/newsarticle/2015/06/09/nab-expands-social-impact-investmentofferings (accessed 3 December 2015).

Cooke, D. 2010. 'Building social capital through corporate social investment.' Asia-Pacific Journal of Business Administration 2(1): $71-87$.

Corporations and Markets Advisory Committee (CAMAC). 2006. The social responsibility of corporations. Report, December. Corporations and Markets Advisory Committee, Canberra.

Department of Foreign Affairs and Trade (DFAT). 2015. Ministerial statement on engaging the private sector in aid and development: Creating shared value through partnership. 31 August. Australian Government, Canberra.

Fox, T., H. Ward and B. Howard. 2002. Public Sector Roles in Strengthening Corporate Social Responsibility: A baseline study. October. Washington, DC: The World Bank. 
Her Majesty's Government (HMG). 2014. Growing the Social Investment Market: 2014 progress update. London: Minister for Civil Society, United Kingdom.

Impact Investing Australia. n.d. Impact Profile: Tim Macready. Melbourne: Impact Investing Australia. Available from: impactinvestingaustralia.com/impact-profile-tim-macready/ (accessed 2 August 2015).

KPMG. 2014. Unlocking the Value of Social Investment. Sydney: KPMG Australia.

Mather, J. 2015. 'Scott Morrison keen to follow NSW into social impact bonds.' Australian Financial Review, 9 September. Available from: afr.com/business/banking-and-finance/investment-banking/scottmorrison-keen-to-follow-nsw-into-social-impact-bonds-20150909gjifh6 (accessed 28 March 2016).

New South Wales Department of Premier and Cabinet (NSW DPC). 2015. Social Impact Investment Policy. Sydney: NSW Government. Available from: dpc.nsw.gov.au/_data/assets/pdf_ file/0011/168338/Social_Impact_Investment_Policy_WEB.pdf (accessed 2 August 2015).

NRMA. 2015. Preparing for the Future. NRMA corporate responsibility review 2014/15. Sydney: NRMA. Available from: mynrma.com.au/ images/About/NRMA_Corporate_Responsibility_Review_2015. pdf (accessed 2 December 2015).

Oppes, A. 2015. 'Implications of new growth phase in Australian impact investing.' SVA Quarterly 13.

Parliamentary Joint Committee on Corporations and Financial Services (PJC). 2006. Corporate responsibility: Managing risk and creating value. Report of the Parliamentary Joint Committee on Corporations and Financial Services, June. Australian Government, Canberra.

Philanthropy Australia. n.d. Fast Facts and Stats. Melbourne: Philanthropy Australia. Available from: philanthropy.org.au/toolsresources/fast-facts-and-stats/ (accessed 2 August 2015). 
Pitt, C. 2015. Social benefit bonds explore new solutions to complex problems. Media Statement by Treasurer, Minister for Employment and Industrial Relations and Minister for Aboriginal and Torres Strait Islander Partnerships, The Honourable Curtis Pitt, 13 July. Parliament House, Brisbane. Available from: statements.qld.gov.au/ Statement/2015/7/13/social-benefit-bonds-explore-new-solutionsto-complex-problems (accessed 28 March 2016).

Porter, M. and M. Kramer. 2011. 'Creating shared value.' Harvard Business Review (January-February).

Remeikis, A. 2015. 'Queensland Labor, LNP agree social benefit bonds are the future.' Brisbane Times, 13 July.

Responsible Investment Association Australasia (RIAA). 2015. Responsible Investment Association Australasia Benchmark Report. Sydney: RIAA.

Senate Economics References Committee. 2011. Investing for Good: the development of a capital market for the not-for-profit sector in Australia. Canberra: Australian Government. Available from: aph. gov.au/Parliamentary_Business/Committees/Senate/Economics/ Completed_inquiries/2010-13/capitalmarket2011/report/index (accessed 27 July 2015).

Social Impact Investment Taskforce. 2014. Impact Investing for Everyone: A blueprint for retail impact investing. London: Social Impact Investment Taskforce. Available from: socialimpactinvestment.org/ subject-papers.php (accessed 16 July 2015).

Social Traders and Queensland University of Technology (QUT). 2010. Social Enterprise in Australia: A preliminary snapshot. Brisbane: Social Traders and QUT.

Social Ventures Australia (SVA). 2015. Re:think. Tax Discussion Paper. Social Ventures Australia, Sydney. Available from: bettertax.gov. au/files/2015/03/TWP_combined-online.pdf (accessed 9 December 2015).

South Australian Government (SAG). 2015. Building a stronger society. A discussion paper on social impact investment. 18 December. Economic Analysis Division, Department of the Premier and 
Cabinet, Adelaide. Available from: assets.yoursay.sa.gov.au/ production/2013/12/18/00_24_24_430_Building_a_Stronger_ Society_web_version_.pdf (accessed 28 March 2016).

Treasury. 2014. Financial System Inquiry Interim Report. Canberra: Australian Government. Available from: fsi.gov.au/publications/ interim-report/ (accessed 21 July 2015).

Wikipedia. 2016. 'Benefit corporation.' Wikipedia. Available from: en.wikipedia.org/wiki/Benefit_corporation (accessed 28 March 2016).

Wood, D., B. Thornley and K. Grace. 2013. 'Institutional impact investing: Practice and policy.' Journal of Sustainable Finance \& Investment 3(2): 75-94.

World Economic Forum (WEF). 2013. From the Margins to the Mainstream: Assessment of the impact investment sector and opportunities to engage mainstream investors. Geneva: World Economic Forum. Available from: iris.thegiin.org/research/fromthe-margins-to-the-mainstream/summary (27 July 2015). 
This text is taken from The Three Sector Solution: Delivering public policy in collaboration with not-for-profits and business, edited by John Butcher and David Gilchrist, published 2016 by ANU Press, The Australian National University, Canberra, Australia. 